\title{
Microbiological efficiency tests of the cosmetic tools disinfection procedures
} https://doi.org/10.21698/rjeec.2020.104

Original research

\section{MONICA ALEXANDRA VAIDEANU ${ }^{1,2}$, DRAGOS RADULESCU* ${ }^{* 1,3}$, ALINA ROXANA BANCIU $^{1}$, DANIELA IONICA ${ }^{1}$, MIHAI NITA-LAZAR ${ }^{1}$}

\author{
${ }^{1}$ National Research and Development Institute for Industrial Ecology-ECOIND, 71-72 Drumul Podu Dambovitei, \\ 060652, Bucharest, Romania \\ ${ }^{2}$ University of Bucharest, Faculty of Chemistry, Department of Organic Chemistry, Biochemistry and Catalysis, Regina \\ Elisabeta Blv., No 4-12, S3, Bucharest, 030018, Romania \\ ${ }^{3}$ Ecological University of Bucharest, Vasile Milea Blv, $N^{o} 1 G$, S6, 061341, Bucharest, Romania \\ *corresponding author (e-mail): radulescudragos91@gmail.com
}

\begin{abstract}
In the last decade, the cosmetic industry has experienced a massive development, but there have also been issues related to their influence on the health of the population. The application methods of the cosmetic products could trigger the appearance of the skin infectious, which raise the need for efficient disinfection processes of the cosmetic products. At the present, the economic operators in the field of cosmetics are guided by medical regulations, but unfortunately, there are not standardized procedure for the application and control of disinfection.

The aim of this study was to determine an efficient procedure of disinfection for instruments used in the application of cosmetics such as the beauty blender. There were performed two different disinfection procedures, a chemical disinfection using $70 \%$ ethanol and a physical disinfection with UV radiation. The influence of foundation on disinfection procedures was also tested. A standardized S. aureus and a $S$. haemolyticus bacterium from a human abscess were tested and an antibiotic resistance pattern was also analysed.

The disinfection efficiency tests showed that the ethanol solution was effective after 5 minutes, decreasing the S. haemolyticus bacterial density by 50\% in the absence of foundation. In the presence of the foundation, this process was no longer efficient, foundation having a possible protection and nutritional role for bacteria. The radiation with $U V$ at $265 \mathrm{~nm}$ showed a complete eradication of both bacterial strains after 1 minute, regardless of foundation presence or not.

The antibiotic susceptibility tested showed that both strains had the natural penicillin resistance.
\end{abstract}

Keywords: Staphylococcus spp., disinfection, cosmetics

\section{INTRODUCTION}

The cosmetic product have been defined by the European Parliament (Regulation (EC) No 1223/2009) as: "any substance or mixture intended to be placed in contact with the external parts of the human body with a view exclusively or mainly to cleaning them, perfuming them, changing their appearance, keeping them in good condition or correcting body odours" [1]. In 2001 the cosmetics industry was worth $\$ 22.5$ million, the areas where the highest market growth was observed were: North America, Europe and Asia [2].

Bashir et all. [3] conducted a study on 497 used cosmetics including lipsticks, eyeliners, lip gloss, mascara and beauty blenders to determine the percentage of infection and the type of microorganisms of these products. Almost all of this products had a bacterial load of $10^{2}-10^{3}$ CFU (Colony-Forming Unit)/ $\mathrm{mL}$ except the beauty blender where the bacterial load was much higher up to $10^{6} \mathrm{CFU} / \mathrm{mL}$. It had been showed that beauty blenders were highly contaminated followed by eyeliner and mascara. Furthermore, they were identified 48 microorganisms of which 10 were found on the beauty blender. Examples of identified bacteria including strains with pathogenic potential such as Staphylococcus aureus, Escherichia coli, Citrobacter freundi, Pseudomonas aeruginosa. The beauty blenders presented the highest rate of contamination with Enterobacteriaceae $(26.85 \%)$ [3]. In another study, showed that 52 shared cosmetic products from beauty salons were highly microbiological contaminated having >500 CFU/g Staphylococcus spp. and E. coli [4]. The first defence system against these pathogens is the skin, specifically keratinocytes, the main cells in the stratum corneum of the 
epidermis involved in the immune response. These cells have receptors for recognizing microorganisms and signal an inflammatory response. Any breech of the skin provides a site where the bacteria could invade and multiple triggering an immune response such as abscess formation (Fig. 1). These is one the defence paths to remove the pathogen by generating abscesses filled with viable leukocytes, necrotic leukocytes, tissue debris, fibrin and infectious agents [5].

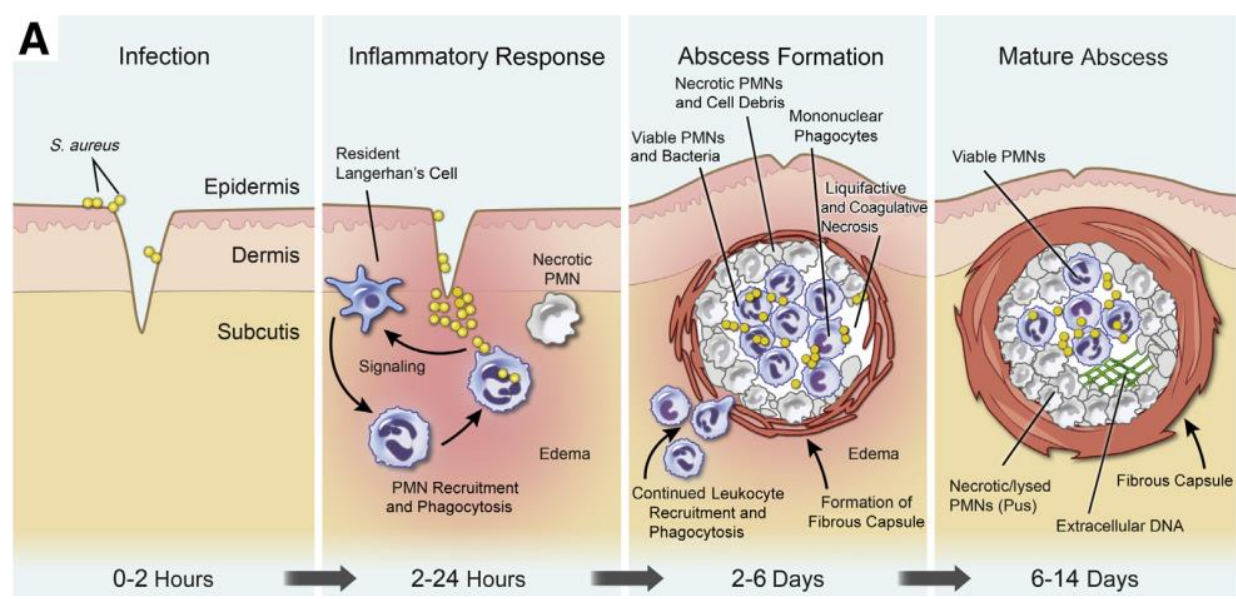

Fig.1. The evolution of an abscess according to Kobayashi et all. [5]

It is a known fact that bacterial infections require a treatment with antibiotics. Their uncontrolled application, in order to fight these infections, leads to the phenomenon of antibiotic resistance with implications both in the health of the population and in the disinfection processes, respectively.

Antibiotics have been defined as a group of chemicals obtained by biosynthesis, semisynthesis or chemical synthesis used to fight against bacteria inducing a bacteriostatic or bactericide effects. Antibiotics are classified according to their chemical structure in beta lactams that contain a beta-lactam ring (Penicillin), aminoglycosides (Kanamycin and Gentamycin), macrolides that contain a macrocyclic lactone ring (Eryhtromycin) [6]. The antibiotics with bacteriostatic effect are macrolides, amphenicols, sulphonamides and tetracyclines and aminoglycosides, beta-lactams, glycopeptides have a bactericide effect [6].

The intensive use of antibiotics in agriculture and by human consumption has led to the emergence of antibiotic resistant genes (ARG) generating antibiotic resistant bacteria (ARB). Bacteria are able to adapt very fast to new chemical compounds from the antibiotic composition, for instance, Linezolid was introduced on the market (in the year of 2000) and after only one year $S$. aureus developed resistance to this antibiotic [6].
The term disinfection refers to the procedure of destroying most pathogenic or non-pathogenic microorganisms from any surface, using physical and/ or chemical agents. When choosing a disinfectant three criteria must be considered: the efficacy, safety and the compatibility with the material. The most important characteristics of the disinfectant are: the activity on a wide spectrum of microorganism, fast, low toxicity or even its absence, high stability, lack of toxic residues, environmental friendly [7]. There are two main types of procedures when it comes to disinfection, chemical disinfection and physical disinfection. The chemical disinfections refers to use of chemical substances for example: alcohols, acids and esters, aldehydes, iodophors etc. From the alcohol class, the most used compounds are ethyl alcohol and isopropyl alcohol. The optimum concentration for these compounds for the best efficacy is $60-90 \%$ solutions in water $(\mathrm{v} / \mathrm{v})[7,8]$.

The UV spectrum is between 200 and $400 \mathrm{~nm}$, and can by classified in UV-A, long wave, and it is in the range of $315-400 \mathrm{~nm}$, the medium wave (UV-B) and UV-C or short wave between 200 and $280 \mathrm{~nm}$ the last one being responsible for the bactericidal effect, for maximum efficiency $265 \mathrm{~nm}$ is wavelength recommended [7].

Alcohols and the UV light have two different mode of action that determine their bactericidal 
effect. Alcohols are responsible for the denaturation of the proteins and the UV causes photochemical reactions at the level of nucleic acids in DNA and ARN [7-9].

In 2007, Rea Ann Silva launches the beauty blender on the market, a reusable cosmetic tool used to apply foundation and other cosmetic products [10]. They can represent substrate for bacterial development, being hydrophilic porous products, allowing the multiplication of bacteria followed by their interactions and invasion of the human cells [3]. Bacteria such as S. aureus

\section{MATERIALS AND METHODS}

\section{Bacterial strains}

$S$. aureus ATCC (American Type Culture Collection) 6538 and S. haemolyticus from a human infectious process were used for this study. S. haemolyticus was isolated from a human abscess using a sterile swab and seeded

\section{Bacterial identification}

Omnilog is an automatic system, which allow the rapid identification of Gram negative and Gram-positive bacteria based on their metabolic reactions, and the results are compared with the database from the manufacturer. For the

\section{Bacterial antibiotic susceptibility}

The antibiotic susceptibility of both bacterial strains was determine by the disc diffusion method according with CLSI (The Clinical\& Laboratory Standards Institute) recommendations. Shortly, bacteria were seeded on the growth medium, after which the discs

\section{Disinfection methods}

The beauty blenders and the foundation cream used for testing were bought from a local beauty store. The beauty blender was cute into $1 \mathrm{~cm}^{3}$ pieces. The growth medium for all of the tests was Nutrient Agar (Oxoid, UK). The bacterial strains were inoculated in Petri dishes: $1 \mathrm{ml}$ of bacterial suspension with known density: for $S$. aureus $982 \mathrm{CFU} / \mathrm{ml}$ and for S. haemolyticus $1563 \mathrm{CFU} / \mathrm{ml}$. For each test, a positive control (bacterial strain with culture medium), a control medium culture and a negative control (culture medium with foundation) were analysed. The disinfection efficiency was measured by the variation of the bacterial density. and S. haemolyticus, conditioned pathogenic bacteria, have been responsible for a multitude of diseases for example folliculitis, boils, mastitis, endocarditis, sepsis, pneumonia as well as for hospital-acquired infections [11, 12].

Being a recent product on the market, there is not yet a well-established methodology for its disinfection and the aim of this work was to determine the efficiency of two physicochemical methods of disinfection on the beauty blenders and to determine the influence of the foundation on this process.

on Nutrient Agar medium then the plate was incubated at $37^{\circ} \mathrm{C}$ for $24 \mathrm{~h}$. Then, it was isolated and identified using the system Omnilog (Biolog, USA).

identification it was used an IF-A inoculum and a GEN III plate. The parameters for this procedure were time of incubation $(22 \mathrm{~h})$ and the temperature of incubation $\left(33^{\circ} \mathrm{C}\right)$.

with antibiotics were placed at equal distances and were incubated for $18 \mathrm{~h}$ at $37{ }^{\circ} \mathrm{C}$. The results were interpreted with an automatic reader (SCAN 500, FR) that compared the diameter of the inhibition zone obtained with the one mentioned in the standard [13].

The bacteria were inoculated in $100 \mathrm{~mL}$ DSW (distilled sterile water). After that a serial dilution was performed using $10 \mathrm{~mL}$ of the bacteria suspension with $100 \mathrm{ml}$ DSW. The beauty blender was introduced into the dilute solution, two solutions were made, one with foundation and the other one without foundation. After which, $10 \mathrm{ml}$ of solution were taken and place in $90 \mathrm{~mL}$ of $70 \%$ ethanol solution or in the $90 \mathrm{~mL}$ of DSW for the UV testing. After each time of contact $1 \mathrm{ml}$ from the tested solution were taken and inoculated on Petri dishes over which $15 \mathrm{ml}$ of agar growth medium were added. The plates were incubated 
for $24 \mathrm{~h}$ at $37^{\circ} \mathrm{C}$. All tests were performed in sterile containers.

Alcohol disinfection tests were performed with $70 \%$ ethanol solution from ethanol absolute (Merck) and DSW. The UV disinfection method was performed at two wavelengths $265 \mathrm{~nm}$ and $365 \mathrm{~nm}$ from two different $\mathrm{Hg}$ vapour lamps.

\section{RESULTS AND DISCUSSION}

The bacterial strains collected from the patient were identified with Omnilog system based on their metabolic reactions. The $S$. haemolyticus was identified as the main bacterial strain. This strain belongs to Staphylococcocus spp which is

\section{Test of the antibiotic sensitivity of bacteria}

The susceptibility tests were performed according with CLSI(2012) recommendations using 6 antibiotics to determine the antibiotic resistance: gentamicin (GEN), kanamycin (K), penicillin $(\mathrm{P})$, clindamycin $(\mathrm{CLI})$, ciprofloxacin (CIP) and trimethoprim-sulphamethoxazole (SXT).

The susceptibility tests were performed on $S$. aureus (Table 1) and S. haemolyticus (Table 2), identified above. $S$. aureus it is a member from the same spp (group/family) and it is closed related to $\mathrm{S}$ h. Moreover, S. aureus is a known bacteria to developed and adapt to antibiotics such as penicillin these bacteria developed such a high resistance to this antibiotic that in the $50 \mathrm{~s}$
Disinfection methods were tested over three contact times ( 1 minute, 5 minutes and 10 minutes) in the presence or the absence of the foundation. The controls for this experiments were: the foundation, the beauty blender, DSW and the alcohols.

Gram-positive, aerobic, facultative anaerobic, non-sporulated, catalase positive bacterium which belongs to the Micrococcaceae family [14].

this drug was no longer recommended for the infections with it. In only two years from the appearance of methicillin, S. aureus adapted and the resistance to this drug determine a new type of bacteria, the Methicillin-resistant Staphylococcus aureus (MRSA), this resistance spread all over the world in the next decades. In the last 20 years, this bacterium has acquired resistance to other antibiotics, the most notable case being the resistance to vancomycin. In the year 2013, the Centres for Control and Prevention classified MRSA as a "serious threat" because it is present in over $30 \%$ of people causing 80.461 severe infections every year and 11.285 deaths $[6,15]$.

Table 1. S. aureus sensibility to antibiotics

\begin{tabular}{l|ccc}
\hline Antibiotic (concentration) & Result & Inhibition area & CLSI limits \\
\hline GEN $(10 \mu \mathrm{g})$ & $\mathrm{S}$ & $30.5 \mathrm{~mm}$ & $12 / 15$ \\
\hline $\mathrm{P}(10 \mu \mathrm{g})$ & $\mathrm{R}$ & $23.2 \mathrm{~mm}$ & $28 / 29$ \\
\hline CLI $(2 \mu \mathrm{g})$ & $\mathrm{S}$ & $35.7 \mathrm{~mm}$ & $14 / 21$ \\
\hline $\mathrm{K}(30 \mu \mathrm{g})$ & $\mathrm{S}$ & $25.2 \mathrm{~mm}$ & $13 / 18$ \\
\hline CIP $(5 \mu \mathrm{g})$ & $\mathrm{S}$ & $36.2 \mathrm{~mm}$ & $15 / 21$ \\
\hline SXT $(25 \mu \mathrm{g})$ & $\mathrm{S}$ & $38.3 \mathrm{~mm}$ & $10 / 16$ \\
\hline
\end{tabular}

Table 2. S. haemolyticus sensibility to antibiotics

\begin{tabular}{l|ccc}
\hline Antibiotic (concentration) & Result & Inhibition area & CLSI limits \\
\hline GEN $(10 \mu \mathrm{g})$ & $\mathrm{S}$ & $26.4 \mathrm{~mm}$ & $12 / 15$ \\
\hline $\mathrm{P}(10 \mu \mathrm{g})$ & $\mathrm{R}$ & $27.6 \mathrm{~mm}$ & $28 / 29$ \\
\hline CLI $(2 \mu \mathrm{g})$ & $\mathrm{S}$ & $22.9 \mathrm{~mm}$ & $14 / 21$ \\
\hline $\mathrm{K}(30 \mu \mathrm{g})$ & $\mathrm{S}$ & $30.8 \mathrm{~mm}$ & $13 / 18$ \\
\hline CIP $(5 \mu \mathrm{g})$ & $\mathrm{S}$ & $39.0 \mathrm{~mm}$ & $15 / 21$ \\
\hline SXT $(25 \mu \mathrm{g})$ & $\mathrm{S}$ & $32.2 \mathrm{~mm}$ & $10 / 16$ \\
\hline
\end{tabular}

According to the results, both bacterial strains other hand, the results showed a major show a natural resistance to penicillin. On the sensibility of both bacterial strains to other type 
of antibiotics such as gentamicin and kanamycin from the class of aminoglycosides, clindamycin

a lincosamide and ciprofloxacin belonging to fluoroquinolones.

\section{Testing the effectiveness of disinfection methods}

The bacterial strains showed a robust growth (Figure 2) which was maintained in the presence of foundation (data not shown).

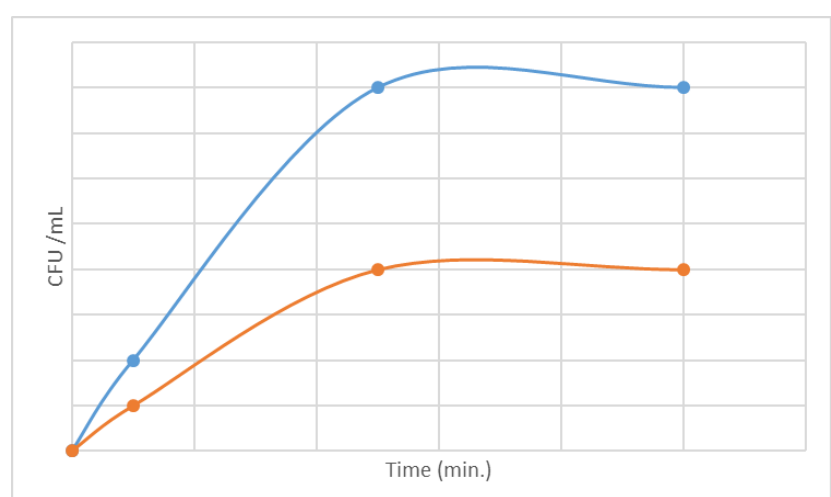

Fig 2. Bacterial growth curves ( Blue- $S$. aureus vs. Orange $S$. haemolyticus)

The results showed that $S$. haemolyticus was resistant to alcohol and a $50 \%$ decrease of the bacterial density was observed at each contact time. This result may be due to the fact that it is an in vivo bacteria that has might have acquired alcohol resistance from a previous and repeatedly exposure. Although S. aureus is a standardized bacteria with a high rate of multiplication in vitro, the effect of alcohol proves to be bactericidal after only 5 minutes of contact time ( $100 \%$ efficiency). Regarding the

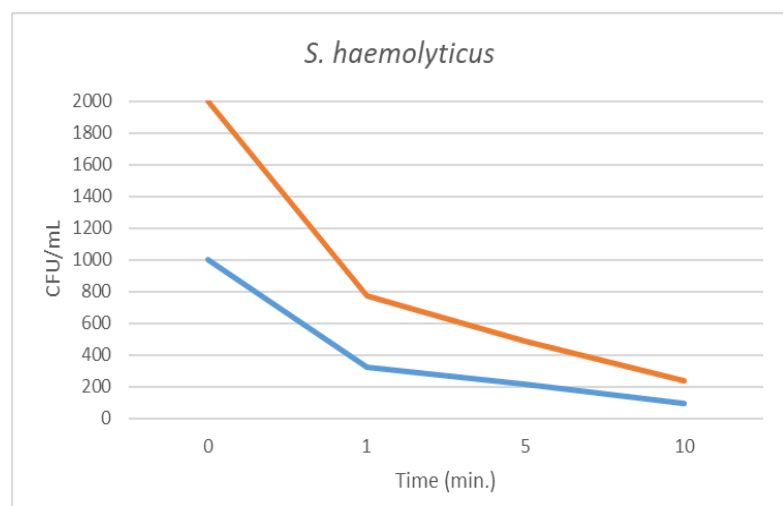

Fig. 3a) The bacterial inhibition by $70 \%$ ethanol for S. haemolyticus (Blue- in the presence of foundation; Orange- in the absence of foundation) influence of the foundation, it decreases the alcohol bactericidal effect (Figures 3a and 3b). The process of physical disinfection with UV radiation (Figure 4) applied for both bacterial strains, it was observed that yield of UV-A radiation is very low $(20 \%)$ and in the case of UV-C radiation the yield was $100 \%$ after 1 minute.

In the case of this disinfection method, the foundation cream did not influence the disinfection process (data not shown).

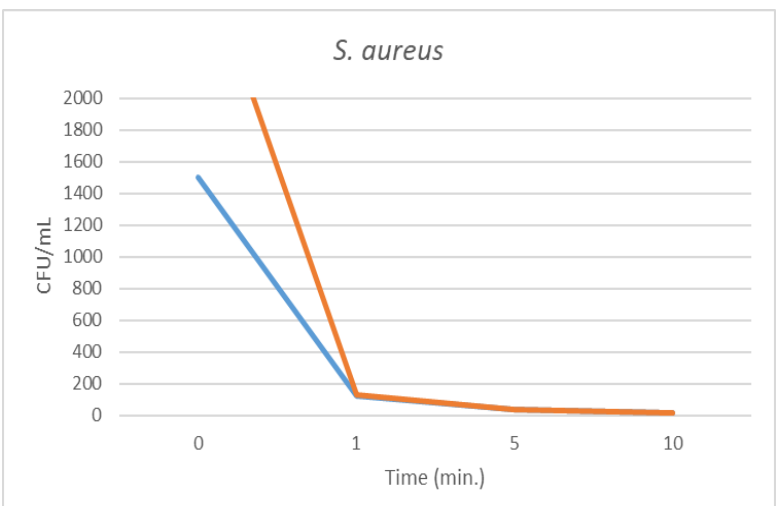

Fig. 3b) The bacterial inhibition by $70 \%$ ethanol for $S$. aureus (Blue- in the presence of foundation; Orange- in the absence of foundation) 


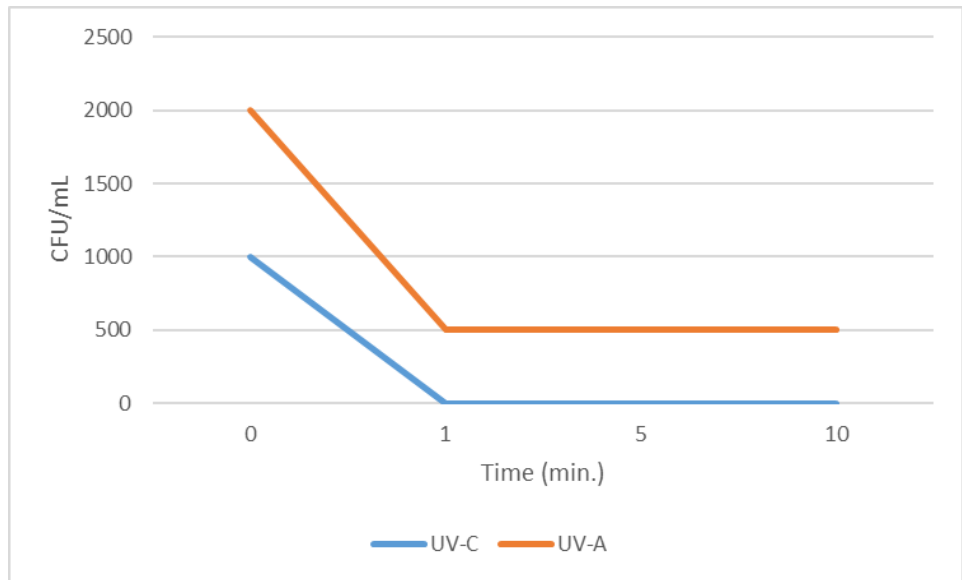

Fig. 4. The bacterial inhibition with UV radiation

\section{CONCLUSIONS}

The microorganisms of interest were represented by a standardized strain of $S$. aureus and a strain of $S$. haemolyticus taken from a human sample. Both of the strains showed the same antibiotic resistance pattern for the penicillin like compounds.

Testing the efficiency of $70 \%$ ethanol showed that $S$. haemolyticus has the ability to resist in the absence of foundation, this phenomenon maybe caused by the potential exposure to this product on human skin,. The alcohol has bactericidal for $S$. aureus after a very short time of exposure ( 5 minutes), the efficiency may be possible due to the fact that it was not exposed to this product before testing.

Following the irradiation process, UV-A radiation was ineffective but the UV-C radiation showed bactericidal activity after 1 minute. This process was not influenced by the presence of foundation.

Overall, foundation could modulate the disinfection process and the cosmetic tools in contact with foundation could be disinfected only by specific methods such as UV-C exposure.

\section{ACKNOWLEDGEMENTS}

This work was financially supported by Nucleu Program SMARTWAY (Reference: PN 19-04 02 01, Contract No 20N/2019) from the Romanian National Authority for Scientific Research and Innovation CNCS/CCCDI-UEFISCDI.

\section{REFERENCES}

[1] EC Regulation 1223/2009 of the European Parliament and of the Council of 30 November 2009 on cosmetic products.

[2] KUMAR, S., Technovation, 25, no. 11, 2015 p 1263.

[3] BASHIR, A., LAMBERT, P., J. Appl. Microbiol., 128, no.2, 2020, p. 598.

[4] DADASHI, L., DEHGHANZADEH, R., Health Promot. Perspect., 6 no.3, 2016, p. 159.

[5] KOBAYASHI, S. D., MALACHOWA, N., DELEO, F. R., Am. J. Pathol., 185, no. 6, 2015, p. 1518.

[6] GALAON, T., BANCIU, A., CHIRIAC, F.

L., NITA-LAZAR, M., Romanian Journal of Ecology \& Environmental Chemistry, no. 1, 2019, p. 16.
[7] MCDONNELL, G. E., Antisepsis, Disinfection, and Sterilization: Types, Action, and Resistance, Second Edition, ASM Press, 2017 Chapter 1; Chapter 8, p. 76-77; 97-99.

[8] Centers for Disease Control and Prevention https://www.cdc.gov/infectioncontrol/guidelines /disinfection/disinfection-methods/index.html

[27.04.2020]

[9] Centers for Disease Control and Prevention https://www.cdc.gov/infectioncontrol/guidelines /disinfection/disinfectionmethods/chemical.html [27.04.2020] [10] Beauty blender https://beautyblender.com/pages/our-story [27.04.2020] 
[11] SACAREA F. T., Medical Bacteriology, [14] LICKER, M., HOGEA, E., University Press Targu -Mures, 2006, p. 5-6, [in CRACIUNESCU, M., HORHAT, F., Romanian]. VADUVA, D. B., DUGAESESCU, D., [12] Centers for Disease Control and Prevention STANGA, L., POPA, M., MUNTEAN, D., https://www.cdc.gov/hai/organisms/staph.html [27.04.2020] RADULESCU, M., PILUT, C., BAGIU, I., [13] Clinical and Laboratory Standards Institute, RUS, M., CIOFLEC, D. B., Microbiology. Performance Standards for Antimicrobial Susceptibility Testing, January 2012. Special Guide for laboratory use, Victor Babes University of Medicine and Pharmacy, Timisoara, 2019, p.5-6, [in Romanian]. [15] Antibiotic resistance threats in the United States, 2013, U. S. Department of Health and Human Services, Centers for Disease Control and Prevention. 